\title{
Recruitment and Training of Employee Followed by Vishal Mega Mart
}

\author{
J.Pavithra, Magdalene Peter, D.S.Varsha
}

\begin{abstract}
The undertaking was finished so one can pick out the effectiveness of the worker pride level closer to the recruitment and schooling manner going on inside the corporation. The powerful become measured utterly based totally at the opinion of the employees and workers in all level, it's also analyzed with various statistically announcement and studied approximately the sources. The examine turned into finished because the management wanted to find out the various factors that affected the advantages of the schooling for the personnel. corporation is imparting education programs and seminars, and numerous different improvement applications also. on the subject of those info a established questionnaire changed into prepared. Which became used to get response from a pattern of 250 personnel? on this have a look at Descriptive research design turned into used and comfort Sampling approach was used as the sampling process, and records obtained were statistically analyzed the usage of Chi-rectangular test and Kolmogrov Smirnov D take a look at and Kendall's Concordance check. The evaluation and interpretations enables to identification the findings and suggestion of the workers. Recruitment bureaucracy the primary level within the process which keeps with choice and ceases with the location of the candidate. it is the next step within the procurement feature the primary being the manpower planning. Recruiting makes it viable to gather the range and kinds of humans essential to make certain the ongoing operation of the corporation. Recruiting is the discovering of potential applicants for actual or expected organizational vacancies. In other words, it's far a linking interest bringing together these with jobs and people seeking jobs. Recruitment has been seemed because the maximum vital characteristic of personnel administration, because unless the proper type of humans are hired, even the exceptional plans, agency charts and control systems might not do much correct. Recruitment both as high-quality? and terrible? hobby. it's far a procedure of trying to find potential personnel and stimulating and inspiring them to apply for jobs to boom the hiring ratio?, i.e., the range of applicants for a task. selection, on the other hand has a tendency to be poor as it rejects a great member of who follow, leaving most effective the pleasant to be employed . [1],[3],[5]
\end{abstract}

Keywords : Training,Employee,Recruitment

\section{INTRODUCTION}

Recruitment paperwork the first level in the procedure which continues with choice and ceases with the position of the

Revised Manuscript Received on July 22, 2019.

J.Pavithra Department of MBA, Bharath Institute of Higher Education and Research, Tamilnadu, India. Email: pavithralect@yahoo.com

Magdalene Peter,Department of MBA, Bharath Institute of Higher Education and Research, Tamilnadu, India. Email: magdalene.bsb@gmail.com

D.S.Varsha, Department of MBA, Bharath Institute of Higher Education and Research, Tamilnadu, India.. Email: varshads@ gmail.com candidate. it is the next step in the procurement function the first being the manpower planning. Recruiting makes it viable to collect the wide variety and styles of people vital to make certain the continued operation of the agency. Recruiting is the discovering of capacity applicants for real or predicted organizational vacancies. [2 ],[ 4],[6]In other words, it's far a linking hobby bringing collectively those with jobs and those searching for jobs. Recruitment has been seemed because the most essential function of employees administration, because except the proper kind of humans are hired, even the satisfactory plans, agency charts and manipulate structures would not do a whole lot top. Recruitment both as 'fine' and 'terrible' activity. 'it's miles a technique of searching for prospective personnel and stimulating and inspiring them to use for jobs to increase the 'hiring ratio', i.e., the quantity of applicants for a process. selection, alternatively has a tendency to be negative as it rejects an excellent member of who observe, leaving only the first-rate to be employed". [7],[ 9], [11]

\section{OBJECTIVES OF THE STUDY}

The basic objectives of training are as follows:

- To identify problems of line manger this may be overcome with the help of training.

- To enhance the effectiveness of present training programs vis-à-vis identified problems.

- To identify training needs of the employees in the division.

- To involve line managers by initiating the process of participative management in the training function.

\section{RESEARCH METHODOLOGY}

A. studies' method a scientific and systematic for pertinent information on a specific topic. research is a cautious investigation or inquiry mainly thru search for new facts in any department of expertise. studies comprises defecting and redefining problems, formulating speculation or advised answers, accumulating .organizing and comparing records; making deductions and reaching conclusions; and at remaining carefully trying out the conclusions to determine whether or not they match the formulating speculation. 'method' is described as "the study of methods with the aid of which we gain information, it deals with cognitive methods imposed on studies through the issues rising from the nature of its concern rely" [8],[ 10], ,[12] 


\section{A. TYPE OF RESEARCH}

Descriptive studies has been used; it entails surveys and truth findings enquire of different kinds the fundamental motive of descriptive research is the description of the scenario, as it exists at present. the main characteristics of this technique are that the nation researcher has no manage over the variable; he can best report what has passed off or what's occurring. The methods of studies utilized in descriptive research are survey techniques of all kinds, consisting of comparative and correlation techniques.. [13], [15] ,[ 17]

\section{B. RESEARCH INSTRUMENT}

The studies instrument used in the look at "dependent questionnaire" established questionnaire are the ones questionnaire in which there are predetermined query relating to the issue. For which the researcher acquire the facts. The questions are presented with exactly the equal wording and order to all the respondents. [14],[ 16], [18]

\section{SAMPLE PROCEDURE}

Convenience sampling has been used on this study. convenience sampling is used for choice of homogeneous pattern for the have a look at. It refers to selecting a sample of look at objects on comfort. it's miles a non-probability sampling. therefore research have a look at may additionally include take a look at objects, that are without difficulty located. studies findings primarily based on convenient sampling however, can not be generalized.s. [19],[21],[23]

\section{LIMITATION OF THE STUDY}

Convenience sampling has its very own time hindrance because the possibilities of right humans on being decided on can be much less. [20],[ 22], [24]

- Time is the primary constraint as it's far difficult to satisfy all of the personnel of the business enterprise inside a brief duration.

- Value is likewise the primary constrain as this research involves huge quantity for the reason of getting ready the record. [25],[27],[29]

Table :1 Showing the opinion of the respondent about the salary

\begin{tabular}{|c|c|c|c|c|}
\hline SI.NO & Description & & No. of Respondent & Percentage \\
\hline 1 & Satisfied & & 62 & 62 \\
\hline 2 & Neither & nor & 29 & 29 \\
\hline 3 & Dissatisfied & & 9 & 9 \\
\hline & Total & & 100 & 100 \\
\hline
\end{tabular}

\section{Interpretation}

- $62 \%$ of employees are satisfied with their salary

- $29 \%$ of employees are neither satisfied nor dissatisfied with salary

- $9 \%$ of employees are dissatisfied with their salary

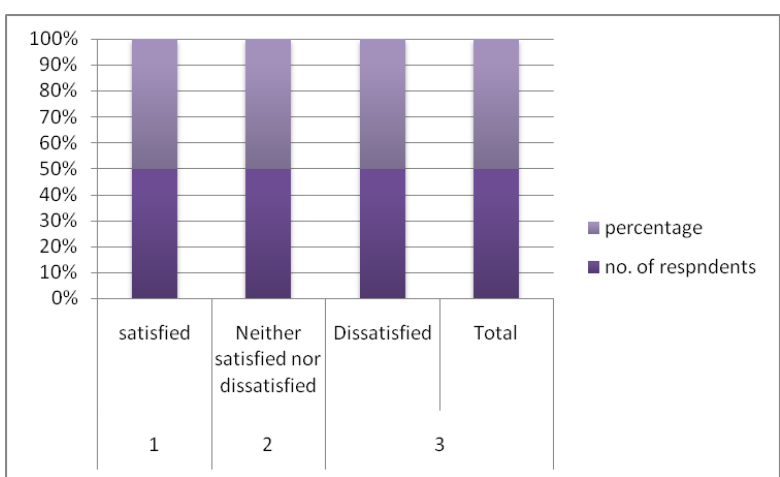

Fig:1 Showing the opinion of the respondent about the salary

Table :2 showing the satisfaction level of the employees towards the promotion policy

\begin{tabular}{|c|c|c|c|}
\hline SI.NO & Description & No. of Respondent & Percentage \\
\hline 1 & Satisfied & 58 & 58 \\
\hline 2 & $\begin{array}{lll}\text { Neither } & \text { satisfied } & \text { nor } \\
\text { dissatisfied } & & \\
\end{array}$ & 31 & 31 \\
\hline \multirow[t]{2}{*}{3} & Dissatisfied & 11 & 11 \\
\hline & Total & 100 & 100 \\
\hline
\end{tabular}

\section{Interpretation}

- 58\% of employees are satisfied by the promotional policy

- $31 \%$ of employees are neither satisfied nor dissatisfied by the promotional policy

- $11 \%$ of employees are dissatisfied by the promotional policy[26],[28],[30]

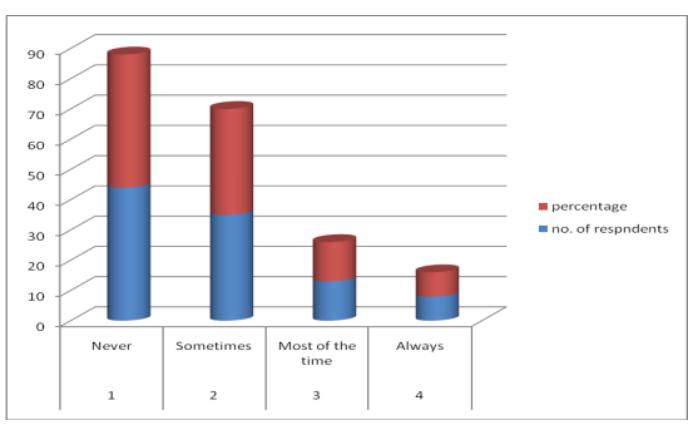

Fig:2 Satisfaction Level Of The Employees Towards The Promotion Policy

\section{RESULTS}

Via the cease of the research we need to provide our guidelines and suggestions to the company wherein we've got executed the initiatives. We want to factor out their faults as well as provide the answers to the issues which have been identified. [31],[33],[35] 


\section{DISCUSSION}

- The employees feel that the organization should improve the welfare measures.

- The company should develop the training and development programme for employees.

- The frequency of the training programme should increase.

- The company should ensure the employee's job security.

- The company should give opportunities to meet challenging jobs.

- The company should be autonomy and initiative in job.

\section{CONCLusion}

Recruitment is the method of trying to find and attracting candidates for the various job position which stand up from the time to time inside the company. schooling is the technique of teaching new personnel the fundamental abilties they need to perform their job. [32]

In mild of this state of affairs, the existing study highlights the need for schooling, proper coping with of grievances provision of clean operating surroundings and so on; the massive findings will make contributions to formulate and impeccable method on the way to bridge the distance between what they're and what they ought to be.

inside the VISHAL MEGA MART, PATNA, the survey changed into conducted to find out the Recruitment and training level of the pleasure of the employees inside the employer and HR regulations contributing closer to boom of Recruitment level of the personnel and approximately its effectiveness fulfillment fee addition changes introduced forwarded etc; this criteria had been evaluated severely to find out feasible pointers so that during future Recruitment degree program could be taken severe by the employer.sooner or later we want to finish the undertaking via given a completely brief summary of the identical.

\section{REFERENCES}

1. G BharthVajan R., Ramachandran S.,Psychographic dimensions of training,2016,International Journal of Pharmacy and Technology,V-8,I-4,P-23727-23729

2. Balakrishnan P., Bharthvajan R.,A study on human resource planning in hospitals in Chennai City,2014,International Journal of Applied Engineering Research,V-9,I-22,P-7503-7507

3. Priyadarsini P., Bharthvajan R.,Role of emotional intelligence training programme in reducing the stress of the nurses,2014,International Journal of Applied Engineering Research,V-9,I-22,P-7411-7421

4. Kerinab Beenu G., Bharthvajan R.,Empirical analysis on the cosmetic buying behavior of young women in South India,2014,International Journal of Applied Engineering Research,V-9,I-22,P-7361-7366

5. Balakrishnan P., Bharthvajan R.,Whistling in the wind,2014,International Journal of Applied Engineering Research,V-9,I-22,P-7586-7593

6. Krishnan B., Peter M.,Health hazards of Indian Bpo employee-an alarming issue, 2014,International Journal of Applied Engineering Research,V-9,I-22,P-7336-7341

7. Kerinab Beenu G.H., Peter M.,Role of insurance in economic development,2014,International Journal of Applied Engineering Research,V-9,I-22,P-7532-7539

8. Balakrishnan P., Peter M., Priyadarsini P.,Efficiency of safety measures for wellbeing of employees in manufacturing industry,2014,International Journal of Applied Engineering Research,V-9,I-22,P-7376-7382

9. Anbarasi M., Praveen Kumar S.,Online sales promotions of herbal products and its effectiveness towards tanisha.com,2019,Indian Journal of Public Health Research and Development,V-10,I-1,P-195-200

10. Anbarasi M., Praveen Kumar S., Various online marketing and promotions strategies to improve the validation towards the organic products in the pharmaceutical sectors,2019,Indian Journal of Public Health Research and Development,V-10,I-1,P-263-269

11. Loganathan R., Praveen Kumar S.,Grievance handling a key factor for solving issues of employees in an organization,2014,International Journal of Applied Engineering Research, V-9,I-22,P-7483-7491

12. Loganathan R., Praveen Kumar S.,Study on preference of private label brands in super and Hypermarkets,2014,International Journal of Applied Engineering Research,V-9,I-22,P-7327-7335

13. Smitha M., Praveen Kumar S.,Understanding stress and its managementamong the nurses in Chennai city,2014,International Journal of Applied Engineering Research,V-9,I-22,P-7560-7565

14. Kerinab Beenu G.H., Praveen Kumar S.,A study on the investment behavior of Chennai investors in mutual fund schemes,2014,International Journal of Applied Engineering Research,V-9,I-22,P-7520-7525

15. Loganathan R., Praveen Kumar S.,Retention strategies key for organizational productivity,2014,International Journal of Applied Engineering Research,V-9,I-22,P-7443-7447

16. Pavithra J., Ganesan M., Brindha G.,State wise analysis of microfinance sector in India,2016,International Journal of Pharmacy and Technology,V-8,I-4,P-23417-23432

17. Pavithra J., Ganesan M.,A comparative study on microfinance in India and abroad,2016,International Journal of Applied Business and Economic Research,V-14,I-8,P-5471-5476

18. Pavithra J., Ganesan M.,A study on awareness and impact of micro-financial schemes,2016,International Journal of Applied Business and Economic Research,V-14,I-8,P-5449-5460

19. Senthilmurugan P., Pavithra J.,Consumer preference towards organised retailing with reference to Big Bazaar,2014,International Journal of Applied Engineering Research,V-9,I-22,P-7469-7475

20. Senthilmurugan P., Pavithra J.,Implication of social media marketing in growing healthcare industry,2014,International Journal of Applied Engineering Research,V-9,I-22,P-7448-7456

21. Loganathan R., Pavithra J.,Consumer perception towards private label brand over other brands in super markets and hypermarkets,2014,International Journal of Applied Engineering Research,V-9,I-22,P-7355-7360

22. Kerinab Beenu G., Pavithra J.,Tradeâ€"off between liquidity and profitability in logistics industry,2014,International Journal of Applied Engineering Research,V-9,I-22,P-7398-7401

23. Kerinab Beenu G., Pavithra J.,A study on the prospective consumerâ€ $\mathbf{T M}_{\mathrm{S}}$ perception towards utility cars in Chennai city,2014,International Journal of Applied Engineering Research,V-9,I-22,P-7526-7531

24. Pavithra J., Dilli Babu P., Ambuli T.V.,A study on budgetary control at Maruti Service Masters, Chennai,2014,International Journal of Applied Business and Economic Research,V-12,I-2,P-151-161

25. Pavithra J., Dilli Babu P., Ambuli T.V.,A study on customer satisfaction of retro Garments Pvt Ltd, Chennai,2014,International Journal of Applied Business and Economic Research,V-12,I-2,P-381-391

26. Kerinab Beenu G.H., Pavithra J., Senthilmurugan P.,A study on the influence of promotional activities for TATA ARIA among consumers in Chennai,2014,International Journal of Applied Engineering Research,V-9,I-22,P-7572-7578

27. Vijayaragavan S.P.,An investigative expert that's general FBG sensors,International Journal of Mechanical Engineering and Technology,V-8,I-8,PP-1500-1505,Y-2017

28. Vijayaragavan S.P.,Equalization routing protocol for Wi-Fi sensor strategy,International Journal of Mechanical Engineering and Technology,V-8,I-8,PP-1662-1666,Y-2017

29. Karthik B., Kiran Kumar T.V.U., Vijayaragavan P., Bharath Kumaran E.,Design of a digital PLL using 0.35 $\hat{\mathrm{I}}^{1 / 4} \mathrm{~m}$ CMOS technology,Middle East Journal of Scientific Research,V-18,I-12,PP-1803-1806,Y-2013

30. Kanniga E., Selvaramarathnam K., Sundararajan M.,Kandigital bike operating system,Middle - East Journal of Scientific Research,V

31. Jasmin M., Vigneshwaran T., Beulah Hemalatha S.,Design of power aware on chip embedded memory based FSM encoding in FPGA,International Journal of Applied Engineering Research,V-10,I-2,PP-4487-4496,Y-2015

32. Jasmin M.,Optimization techniques for low power VLSI circuits,Middle East Journal of Scientific 
Research,V-20,I-9,PP-1082-1087,Y-2014

33. Jasmin M., Vigneswaran T.,Fuzzy controller for error control of on - Chip communication,2017 International Conference on Algorithms, Methodology, Models and Applications in Emerging Technologies, ICAMMAET 2017,V-2017-January,I-,PP-1-5,Y-2017

\section{AUTHORS PROFILE}

J.Pavithra, Assistant Professor ,Department of MBA Bharath Institute of Higher Education and Research, Tamilnadu, India

Magdalene Peter, Assistant Professor ,Department of MBA, Bharath Institute of Higher Education and Research, Tamilnadu, India

DS.Varsha, Student ,Department of MBA, Bharath Institute of Higher Education and Research, Tamilnadu, India 